\title{
Philosophy in Islam and its limit on teaching reason in humanities
}

\begin{abstract}
This chapter discusses the pedagogical concern about teaching humanities to Muslim students. It provides a background to the problem, describes the nature of humanities and the place of reason in teaching it and the problem with regards to Muslim students' stance on reason. The chapter offers a perspective on where the problem lies within philosophy in Islam. It outlines the implication for pre-service teachers in thinking about their pedagogy. The situation with Muslim students described in the preceding section is related to the phenomenon of Islamic education and its place in the life of Muslims. It draws on S. Akhtar's description of philosophy in Islam and how reason is viewed within its precepts. As humanities teachers, at least in a minimal sense, should be that the aim of humanities education is ensuring the wellbeing of students as it contributes to the flourishing of themselves and others as persons in a polity.
\end{abstract}

